PRAVNA PRAKSA

Vida Petrović-̌̌kero*

\title{
STUDIRANJE I IZDRŽAVANJE
}

\section{Komentar presude Vrhovnog kasacionog suda Rev 3129/10 od 1. septembra 2010. godine}

Upis poverioca izdržavanja u svojstvu studenta koji se finansira iz budžeta Republike Srbije na drugi odsek studija prvog stepena fakulteta na kome je već završio školovanje istog stepena, zbog nemogućnosti zaposlenja, ne predstavlja stručno usavršavanje. Ova činjenica ne može dovesti do ponovnog uspostavljanja zakonske obaveze izdržavanja od strane dužnika izdržavanja, koja je prestala na osnovu pravnosnažne sudske odluke, iako poverilac nije napunio 26 godina života.

Pravnosnažnom sudskom odlukom utvrđeno je da je prestala zakonska obaveza dužnika izdržavanja u odnosu na 24 godina starog poverioca izdržavanja koji je diplomirao na Odseku turizma na Prirodno-matematičkom fakultetu juna 2009. godine. Nije uspeo pokušaj da se zaposli, pa je upisao Odsek fizike na istom fakultetu.

Polazeći od tako utvrđenog činjeničnog stanja prvostepeni i žalbeni sud su zaključili da tužilac kao poverilac izdržavanja ima pravo na zakonsko izdržavanje od strane tuženog - dužnika izdržavanja, shodno članu 155. stav 2. Porodičnog zakona, jer nije navršio 26 godina života i ponovo se nalazi na redovnom školovanju, sada na Odseku fizike Prirodno-matematičkog fakulteta, čime želi da usavrši svoje obrazovanje. Sudovi su zaključili da se tužilac ne može lišiti prava na izdržavanje od strane tuženog, bez obzira što je redovno školovanje na Prirodno-matematičkom fakultetu - Odsek turizma već završio.

Vrhovni kasacioni sud nalazi da je osnovana revizija tuženog. U konkretnom slučaju nisu ispunjeni uslovi za ponovno ustanovljenje obaveze tuženog da tužiocu plaća izdržavanje, shodno članu 155. Porodičnog zakona, zbog čega su preinačene nižestepene presude i odbijen tužbeni zahtev tužioca.

Sudija Vrhovnog kasacionog suda Republike Srbije 


\section{PRAVNA PRIRODA INSTITUTA ZAKONSKOG}

\section{IZDRŽAVANJA I RELEVANTNE ZAKONSKE NORME}

Porodični zakon je odredio pravnu prirodu instituta zakonskog izdržavanja u članu 8, navodeći da je izdržavanje pravo i dužnost članova porodice određeno ovim zakonom. Sedmi deo Zakona utvrđuje članove porodice kojima pripada ovo pravo, ko ima dužnost davanja izdržavanja ${ }^{1}$ i redosled u ostvarivanju ovog prava, odnosno dužnosti. ${ }^{2}$ Zakonska terminologija Porodičnog zakona, „poverilac izdržavanja“ i „dužnik izdržavanja“ određuje da zakonsko izdržavanje ima karakteristike obligaciono-pravnog odnosa u kome zakon uspostavlja dužničko-poverilačke pravne veze koje deluju samo inter partes. Radi se o pozitivnoj obligaciji, obaveze su imovinskog karaktera, s tim što predmet može biti novčana ili nenovčana obligacija. ${ }^{3}$ Poverilac izdržavanja može tužbom zahtevati utvrđenje svog potraživanja. ${ }^{4}$

Pravo na zakonsko izdržavanje proizlazi iz prava na porodični život i Porodični zakon ne uređuje obavezu države u slučaju materijalnog obezbeđenja porodice ili pojedinca. Ovakve norme nalaze se u propisima kojima se reguliše socijalna zaštita i socijalno osiguranje pa se Porodičnim zakonom regulišu samo međusobne obaveze članova porodice.

Izdržavanje može trajati određeno i neodređeno vreme. U slučaju da je poverilac izdržavanja deteta, po pravilu obaveza izdržavanja traje do punoletstva deteta kada prestaje roditeljsko pravo, pa i izdržavanje kao deo sadržine tog prava. Predviđena su dva izuzetka od ovoga pravila:

- kada je punoletno dete nesposobno za rad, a nema dovoljno sredstava za izdržavanje, ono ima pravo na izdržavanje od roditelja sve dok takvo stanje traje $\mathrm{e}^{5} \mathrm{i}$

- punoletno dete koje se redovno školuje ima pravo na izdržavanje od roditelja srazmerno njihovim mogućnostima, a najkasnije do navršene 26. godine života. Nema pravo na izdržavanje punoletno dete ako bi prihvatanje njegovog zahteva za izdržavanje predstavljalo očiglednu nepravdu za roditelja, odnosno druge krvne srodnike. ${ }^{6}$ Zakonska odredba ukazuje da su roditelji dužni da izdržavaju svoje dete koje se redovno školuje do isteka vremena trajanja školovanja u odgovarajućoj školi, odnosno fakultetu, ali u svakom slučaju obaveza prestaje kad dete navrši 26. godinu života, ali je za razliku od obaveze izdrža-

\footnotetext{
1 Čl. 151. do 159. Porodičnog zakona, „Službeni glasnik RS“, broj 18/05.

2 Član 166. Porodičnog zakona.

3 Čl. 161. i 162. Porodičnog zakona.

4 Čl. 278. i 279. Porodičnog zakona.

5 Član 155. stav 1. Porodičnog zakona.

6 Član 155. st. 2. i 4. Porodičnog zakona.
} 
vanja maloletnog deteta u ovome slučaju pravo poverioca izdržavanja punoletnog deteta uslovljeno i postojećim mogućnostima roditelja.

Razvoj i zahtevi savremenog društva nametnuli su pitanje šta se podrazumeva pod redovnim školovanjem, da li postoji obaveza roditelja da izdržava radno sposobno punoletno dete koje je završilo fakultet, a želi dalje da se usavršava i šta predstavlja usavršavanje.

Zakon o visokom obrazovanju predvideo je da su studije prvog stepena:

1. osnovne akademske studije,

2. osnovne strukovne studije.

Studije drugog stepena su:

1. diplomske akademske studije - master,

2. specijalističke strukovne studije,

3. specijalističke akademske studije.

Studije trećeg stepena su doktorske akademske studije. ${ }^{7}$

Lice koje se upiše na odobrene, odnosno akreditovane studijske programe koje organizuje visokoškolska ustanova, pod uslovima i na način uređen zakonom i opštim aktom samostalne visokoškolske ustanove, stiče status studenta. Studenti se upisuju u status studenta koji se finansira iz budžeta ili studenta koji se sam finansira. ${ }^{8}$ Status studenta prestaje između ostalog i u slučaju završetka studija. ${ }^{9}$

Imajući u vidu navedene relevantne zakonske odredbe, te da se status studenta stiče upisom na odobrene, odnosno akreditovane studijske programe koje organizuje visokoškolska ustanova, sudska praksa je izgradila stav da se i studenti koji se finansiraju iz budžeta i studenti koji se sami finansiraju smatraju licima koja se redovno školuju, pod uslovom da redovno izvršavaju fakultetske obaveze i polažu ispite u skladu sa internim propisima fakulteta. Uslov je da se školovanje odvija kontinuirano, bez velikih prekida, ili ako prekidi nisu posledica nemara punoletnog deteta koje se školuje. ${ }^{10}$ Pravni standard „neopravdano ili znatno zaostajanje u studiranju“ mora se utvrđivati u svakom pojedinačnom slučaju, uz ocenu svih relevantnih karakterističnih činjenica.

7 Član 25. stav 4. Zakona o visokom obrazovanju, „Službeni glasnik RS“, br. 76/05, $100 / 07$ i $97 / 08$.

8 Član 82. st. 1, 5. i 6. Zakona o visokom obrazovanju.

9 Član 94. stav 1. tačka 1. Zakona o visokom obrazovanju.

10 „Roditelji su dužni da izdržavaju svoje punoletno dete, koje studira, sve do navršene 26. godine, srazmerno svojim mogućnostima. Za ovu obavezu roditelja bez značaja je okolnost što je dete zaostalo u polaganju ispita, ako taj zastoj nije znatan i ako on nije posledica nemara deteta koje se školuje." (Vrhovni sud Srbije Rev. 1978/83) 
Odredbe Zakona o visokom obrazovanju svrstavaju studiranje u tri stepena školovanja. To ukazuje da bi sva tri stepena predstavljala redovno školovanje, pa bi poverioci izdržavanja u odnosu na dužnika izdržavanja imali mogućnost da ostvare pravo na zakonsko izdržavanje za svaki stepen, do navršene 26. godine života. Pri tome se mora imati u vidu da je u našem obrazovnom sistemu obavezno samo osnovno školovanje, a da neobaveznost obrazovanja postoji i za školovanje u srednjoj i višoj školi, kao i na fakultetu u sva tri moguća stepena.

Upravo ovakva zakonska regulativa daje mogućnost da punoletno dete koje redovno pohađa master ili specijalističke, odnosno doktorske studije do navršene 26. godine života može ostvarivati pravo na izdržavanje pod uslovima iz člana 155. st. 2. i 4. Porodičnog zakona koji se utvrđuju za svaki pojedinačni slučaj.

Pri donošenju odluke o pravu poverioca izdržavanja, mora se imati u vidu da je svrha obrazovanja sticanje mogućnosti za zaposlenje i obavljanje posla za koje je dete školovano, a svrha sticanja većeg stepena obrazovanja treba da obezbedi povećanu mogućnost za zaposlenje i obezbeđenje bolje zarade što će omogućiti bolji kvalitet života. Tako je ranija sudska praksa određivala da je „Završavanjem fakulteta dete zaokružilo školovanje visokog stepena i osposobljeno je za samostalno vršenje određenih poziva. Postdiplomskim studijama se stiče naučni stepen obrazovanja, pa je to stvar ambicije i mogućnosti samog deteta, a ne postoji obaveza njegovih roditelja da finansiraju sticanje takvog stepena obrazovanja." ${ }^{11} \mathrm{Za}$ razliku od ovakvog pravnog shvatanja, imajući $\mathrm{u}$ vidu relevantne zakonske norme, te prateći potrebe doživotnog usavršavanja kao posledice ubrzanog društvenog razvoja, dolazi do promene sudske prakse. U odluci Vrhovnog suda Srbije izraženo je pravno stanovište prema kome student na postdiplomskim studijama i u inostranstvu do navršene 26. godine života ima pravo na izdržavanje od roditelja, s obzirom na to da se i postdiplomske studije smatraju redovnim školovanjem. Dete nije navršilo 26 godina života, pa je roditelj obavezan na davanje izdržavanja na osnovu člana 155. stav 2. Porodičnog zakona. ${ }^{12}$

Međutim, kada se školovanje započne iz razloga da bi se na taj način ostvarilo pravo na izdržavanje, ova činjenica ne može predstavljati osnov za sticanje ovog prava. U konkretnom slučaju, poverilac izdržavanja je završio redovno školovanje na Odseku turizma Prirodno-matematičkog fakulteta. Sudskom odlukom utvrđeno je da je prestala obaveza dužnika izdržavanja da doprinosi izdržavanju poverioca. Prema utvrđenom činjeničnom stanju, punoletno dete je zbog nemogućnosti da se zaposli posle završenih studija, u svojstvu redovnog studenta upisalo drugi odsek - Odsek fizike na istom fakultetu, i kako još nije napunilo 26 godina, pred sudom je pokrenulo postupak da se ponovo konstituiše obaveza dužnika izdržavanja da doprinosi

11 Presuda Vrhovnog suda Vojvodine Rev. 190/83.

12 Rev. 2528/06 od 17. novembra 2006. godine. 
izdržavanju punoletnog deteta kao redovnog studenta. Sud je stanovišta da upis redovnih studija na drugom odseku istog fakulteta ne predstavlja stručno usavršavanje, jer se radi o ponovnom upisu na studije prvog stepena različitog odseka istog fakulteta koje započinje samo iz razloga što nije mogao da se zaposli. Pri tome nije koristilo mogućnost višeg stepena obrazovanja na istom odseku koje bi eventualno povećalo mogućnost zaposlenja i obezbedilo bolje socijalne pozicije, a što je „opravdan razlog za produženje redovnog školovanja i posle završetka studija prvog stepena" (osnovnih akademskih, odnosno osnovnih strukovnih studija). ${ }^{13}$ Punoletno dete ima pravo na izdržavanje od roditelja srazmerno njihovim mogućnostima dok se redovno školuje, a najkasnije do navršene 26. godine života, kako je predviđeno članom 155. stav 2. Porodičnog zakona. Status studenta prestaje u slučaju završetka studija. Kako je poverilac izdržavanja završio studije prvog stepena, a zbog nemogućnosti zapošljavanja rešio da ponovo upiše studije prvog stepena drugog odseka upravo iz ovog razloga, ne bi bilo pravično ponovo konstituisati obavezu dužnika izdržavanja u slučaju ,jednake neobaveznosti obrazovanja“ kada poverilac izdržavanja ponovo upisuje fakultetsko osnovno obrazovanje koje je na drugom odseku već završio. Činjenica ponovnog studiranja istog stepena na drugom fakultetu može biti samo osnov za dobrovoljno davanje izdržavanja od roditelja, ali ne i dovoljan razlog na osnovu koga će sud ponovo konstituisati obavezu izdržavanja punoletnog deteta, što bi moglo voditi prekomernom mešanju države u porodični odnos.

13 Vladan Jovanović, Izdržavanje punoletnog deteta na redovnom školovanju (neobjavljen). 